\begin{tabular}{|c|c|c|}
\hline 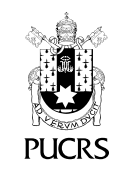 & $\begin{array}{l}\text { ESCOLA DE } \\
\text { HUMANIDADES }\end{array}$ & $\begin{array}{l}\text { Revista Digital do Programa de Pós-Graduação em Letras da PUCRS } \\
\text { Letrônica, Porto Alegre, v. 13, n. 1, p. 1-15, jan.-mar. } 2020 \\
\text { e-ISSN: } 1984-4301\end{array}$ \\
\hline de) $\mathrm{http}: / / \mathrm{dx}$ & $\mathrm{rg} / 10.15448 / 1984-4301.2020 .1 .35145$ & \\
\hline
\end{tabular}

\title{
Circulação da escrita de mulheres hispano-americanas no Brasil: uma crítica a partir da história da tradução
}

\author{
Writing Circulation of Hispano-American women in Brazil: \\ a critique from the translation history \\ Circulación de escrita de mujeres hispanoamericanas en Brasil: \\ una crítica desde la historia de la traducción
}

\section{Andrea Cristiane \\ Kahmann ${ }^{1}$}

orcid.org/0000-0001-8582-9210

ackahmann@gmail.com

Recebido em: 30 jul. 2019. Aprovado em: 30 out. 2019. Publicado em: 7 abr. 2020.

\section{(c) (1)}

Artigo está licenciado sob forma de uma licença Creative Commons Atribuição 4.0 Internacional.
Resumo: Apesar da boa recepção da escrita (literária e não literária) de mulheres (décadas de 1930-1940) e também da literatura hispano-americana (especialmente nos e a partir dos anos 1970) no sistema brasileiro, é ainda proporcionalmente pequeno o número de livros de autoria única de mulheres hispano-americanas em tradução publicados e circulantes na história do livro no Brasil. Para demonstrar esse fenômeno e propor algumas possiveis explicações a ele, este artigo busca postulados da crítica decolonial, centrando-se na história colonial do Brasil e nos seus impactos na história das mulheres e, também, da leitura, do livro e da tradução no Brasil. Por fim, e defendendo que as literaturas traduzidas desempenham um importante papel na transformação de repertórios conservadores, esse artigo relaciona algumas traduções recentes de autoras hispano-americanas e aponta alguns "vazios tradutórios", ou seja, elenca escritoras e obras que, não obstante tenham adquirido fama em seus sistemas literários de origem, não foram postas em circulação pela via da tradução no Brasil.

Palavras-chave: Literatura de mulheres. Crítica decolonial. História da tradução no Brasil. Literatura hispano-americana em tradução. Circulação de literatura traduzida.

Abstract: There is a good reception of women writing (literary and non-literary, since the 1930 - 1940s) and Hispano-American literature (particularly in and since the 1970s) in Brazil. Despite of it, there is still a proportionally small number of books on translation exclusively written by Hispano-American women published and circulating in the book history in Brazil. To present this phenomenon and to propose some possible explanations for it, this work searches for postulates of the decolonial critique, focusing on the colonial history of Brazil and its impacts on the history of women, as well as the history of reading, the book and translation in Brazil. Finally, after arguing that translated literatures play an important role in the transformation of conservative repertoires, this article links some recent translations of Hispano-American authors and points out some "translation gaps". In other words, it lists female writers and works that, despite having acquired fame in their original literary systems, were not put into circulation by way of translation in Brazil. Keywords: Women's literature. Decolonial critique. Translation history in Brazil. Hispano-American literature on translation. Circulation of translated literature.

Resumen: A pesar de la buena recepción de la escrita (literaria y no literaria) de mujeres (desde los años 1930 - 1940) y también de la literatura hispanoamericana (especialmente en y a partir de los años 1970) en el sistema brasileño, es todavia proporcionalmente pequeño el número de libros de autoría única de mujeres hispanoamericanas en traducción publicados y circulantes en la historia del libro en Brasil. Para demostrarlo y plantear algunas posibles explicaciones a este fenómeno, busco postulados de la crítica decolonial, centrándome en la historia del coloniaje en Brasil y sus impactos en la historia de las mujeres y también de la lectura, del libro y de la traducción en Brasil. Por fin, y defendiendo que las literaturas traducidas ejercen un importante rol en la generación de cambios en repertorios conservadores, este artículo relaciona algunas traducciones recientes de autoras hispanoamericanas y refiere algunos "vacios traductores", o sea, 
escritoras y obras que, aunque hayan adquirido fama en sus sistemas literarios de origen, no han sido puestas en circulación por la vía de la traducción en Brasil.

Palabras clave: Literatura de mujeres. Crítica decolonial. Historia de la traducción en Brasil. Literatura hispanoamericana en traducción. Circulación de literatura traducida.

\section{Introdução}

Peter Burke ([2007] 2009, p. 29) refere que, na "economia política da tradução", a "balança comercial" das importações e das exportações entre os vernáculos constitui um relevante indicador para a análise de transferências culturais e relações de poder. Para ele, a historiografia deve atentare, em alguma medida buscar responder às questões: Quem traduz? Com que intenção? O quê? Para quem? De que maneira? Com que consequências? (BURKE, [2007] 2009, p. 17). A mesma importância assume a reflexão sobre o que não se traduz, pois, entendendo-se as traduções como fatos da cultura receptora, os vazios tradutórios los expurgos nos textos, os textos retirados de circulação ou mesmo os textos ignorados em uma determinada cultura embora célebres em outras) são relevantes indicativos para se compreender os tabus e as sensibilidades de um determinado sistema de cultura. Assim, proponho uma discussão sobre o que se traduz e, sobretudo, o que não se traduz como forma de crítica da cultura, ao mesmo tempo em que sugiro a tradução de obras com potencial inovador para a reconfiguração do nosso repertório (ainda) conservador.

Para realizar essa proposta, organizo este artigo em três partes. Na primeira, detenho-me sobre a circulação de obras traduzidas como força de inovação ou conservação de repertórios, a fim de demonstrar as relações de poder que permeiam a produção/tradução/circulação literária-cultural, que, no Brasil, provém, desde as décadas de 1930-1940, majoritariamente da língua inglesa. Em um segundo momento, amparo-me na crítica decolonial e de gênero, aproximandoas aos estudos da tradução e história do (e de mulheres no) Brasil, relacionando a primeira onda de feminismo brasileiro (e o contra-ataque a essa) à intensa atividade tradutória. Por fim, demonstro que a tradução de escritoras hispano-americanas não acompanha o interesse pela tradução de mulheres (sobretudo de lingua inglesa, como nos anos 1930 e 1940) nem o boom da literatura latino-americana (nos anos 1970). Partindo do pressuposto que aquilo que uma cultura não traduz oferece preciosas pistas sobre os seus limites e sensibilidades, identifico alguns (ainda) vazios tradutórios (obras e escritoras precursoras das letras latino-americanas em domínio público à espera de circulação no Brasil pela via da tradução). Com esses três pontos, busco recuperar a história de mulheres e, sobretudo, de escritoras latino-americanas dos séculos XIX e $X X$, e propor esforços para a reconfiguração do cânone (e das práticas) no século XXI.

Este artigo é redigido refutando a linguagem sexista e o uso do masculino genérico. Cabe alertar que, apesar de conhecer e concordar com os manuais que sugerem evitar as barras diagonais e empregar a repetição de masculino e feminino em substantivos e adjetivos de dois gêneros para facilitar a compreensão do texto e conferir mais visibilidade às mulheres (RIO GRANDE DO SUL, 2014), sendo este um texto com limitações de páginas e voltado a um público especializado, opto por empregar estruturas como "os/as autores/as", sem espaço, seguindo a recomendação do Manual pedagógico sobre uso da linguagem inclusiva nãosexista elaborado pela Comissão Permanente de Gênero e Direito das Mulheres da Reunião de Altas Autoridades em Direitos Humanos e Chancelaria do MERCOSUL (RAADH).

\section{A tradução como catalisadora da inovação de repertórios}

De acordo com Lia Wyler, as traduções representam, no Brasil, "80\% dos livros de prosa, poesia e referência, bem como manuais e catálogos" (WYLER, 2003, p. 13). Diante dessas dimensões, que, se contrastadas com países como os Estados Unidos, em que "as traduções de livros estrangeiros não ultrapassam a marca de 2,5 3.5\% do mercado editorial" (WYLER, 2003, p. 13), pode-se afirmar que a literatura traduzida ocupa uma posição central no sistema literário brasileiro. 
Itamar Evan-Zohar identifica três possiveis condicionantes para que a literatura em tradução ocupe posição central em um determinado (polis) sistema literário:

(a) quando um polissistema ainda não se cristalizou, ou seja, quando uma literatura ainda é "jovem", em processo de se estabelecer; (b) quando uma literatura é "periférica" (dentro de um grupo maior de literaturas correlatas), "fraca" ou as duas coisas; e (c) quando ocorrem pontos de virada, crises ou vácuos literários em uma dada literatura (EVEN-ZOHAR, [1990] 2012, p. 5).

Nos dois primeiros casos, seguindo o autor, a literatura pode ainda carecer de uma gama completa de atividades literárias, e a tradução posiciona-se como o mais importante dos recursos para suprir o limitado repertório com textos selecionados de literaturas adjacentes prestigiadas. Contudo, a seleção de obras a traduzir, a depender da constelação específica do (polis)sistema receptor, pode observar parâmetros inovadores ou conservadores. A literatura traduzida opera forças inovadoras (ou "primárias") quando proporciona ao sistema que a acolhe uma inovação de poéticas, técnicas e padrões composicionais. Contudo, a literatura em tradução desempenha forças conservadoras (ou "secundárias") se reforça configurações já presentes no sistema receptor ou se cristaliza uma relação de dependência (Even-Zohar, [1990] 2012).

Sob essa ótica, compreendo a literatura brasileira (se entendida no seu sentido mais estrito, de permanente circulação de textos criativos escritos, geralmente em livro, entre uma comunidade leitora) como uma literatura ainda em processo de se estabelecer e que, portanto, pode encontrar na atividade tradutória as forças para inovação de seu repertório e, assim, impulsionar uma virada não só poetológica, mas ideológica.

Celebrados manuais de história da literatura brasileira remontam ao ano de 1500 para indicar a Carta de Pero Vaz de Caminha a el-Rei D. Manuel como sendo a nossa primeira obra.
Existem aí, a meu ver, dois problemas. O primeiro é a naturalização, nos estudos literários, do que Boaventura de Sousa Santos (2010) denomina pensamento abissal, um sistema de conformação de valores que posiciona a colonização como sendo "o grau zero a partir do qual são construidas as modernas concepções de conhecimento" (SANTOS, 2010, p. 36), como se não existisse língua, cultura, literatura e civilização antes disso. Se for aceita, porém, a intenção de historiografar a escrita literária (como manipulação da linguagem com consciente intenção artística) de conformidade com o que hoje entendemos por literatura e por Brasil, o segundo equívoco em se atribuir à Carta de Caminha a certidão de nascimento² (BOSI, [1994] 2006, p. 14) da nossa literatura provém de que essa, como se a entende hoje, é conformada por um sistema em que existem não apenas escrituras, mas pessoas que as (re)escrevem, que as leem e que as fazem circular.

Apesar dos talentos individuais e das relevantes obras concebidas no Brasil até o século XVIII, há que se ter em vista que estruturas coloniais atrasam significativamente a consolidação de um autêntico sistema de circulação de uma literatura brasileira. Até 1808, quando a Corte portuguesa se transfere para o Rio de Janeiro, são proibidas as tipografias. Mesmo depois de 1808, mantém-se a dependência da Europa: Machado de Assis é publicado por editora francesa (PAES, 1990); de Portugal vêm os livros de Lima Barreto e Olavo Bilac (HALLEWELL, [1975] 2012). O Brasil ingressa no século $X X$ com mais de $80 \%$ de população analfabeta $^{3}$ e uma elite galicizada com pouco apreço pela cultura local, além de uma política a dificultar a importação de maquinário e papel para livros (HALLEWELL, [1975] 2012). Somente a partir da década de 1930, surge no Brasil uma indústria editorial digna do nome (CANDIDO, 1989). Por essa perspectiva, a literatura brasileira pode ser considerada jovem.

Sob outra ótica, a literatura nacional pode ser

\footnotetext{
2 Nas palavras de Bosi: "O que para a nossa história significou uma autêntica certidão de nascimento, a Carta de Caminha a D. Manuel, dando notícia da terra achada, insere-se num gênero copiosamente representado durante o século XV em Portugal e Espanha: a literatura de viagens" (BOSI, [1994] 2006, p. 14, grifo nosso).

3 No primeiro levantamento demográfico da história brasileira, em 1872, foram computadas 8.365.997 pessoas que não sabiam ler nem escrever (84,24\%) contra apenas $1.564 .481 \mathrm{com}$ conhecimento de letras (IBGE, 2018b).
} 
caracterizada como fraca ou periférica por não se configurar como um espaço literário efetivamente autonômico. Os mecanismos de consagração de obras e autores/as são atrelados a dominações (em geral, politicas/econômicas/sociais) e a condicionantes extraliterárias (como gênero, cor, origens, ideologias, habitus, relações de compadrio e parentesco). Este, que é o décimo país mais desigual do mundo em distribuição de renda, e no qual, em 2017, "os 10\% da população com os maiores rendimentos detinham 43,3\% da massa de rendimentos do pais, enquanto a parcela dos $10 \%$ com os menores rendimentos detinha $0,7 \%$ desta massa" (IBGE, 2018a) ainda não se mostra apto a romper com o pensamento abissal (SANTOS, 2010), que delega a uns a civilização e a outros a barbárie, e é tão mais violento quanto mais invisivel conseguir ser. O sistema brasileiro da escrita criativa segue majoritariamente os códigos dos 10\% "de cima" da estratificação econômica. Os que têm condições materiais para se dedicar à escrita literária e têm suficiente trânsito por elites aptas a lhes conferir prestígio nesse campo são, não raro, da mesma cor, do mesmo sexo, e habitantes das mesmas cidades. Como conclui Regina Dalcastagné:

[dentre] os romances publicados pelas principais editoras brasileiras, em um período de 15 anos (de 1990 a 2004), 120 em 165 autores eram homens, ou seja, 72,7\%. Mais gritante ainda é a homogeneidade racial: 93.9\% dos autores são brancos. Mais de $60 \%$ deles vivem no Rio de Janeiro e em São Paulo. Quase todos estão em profissões que abarcam espaços já privilegiados de produção de discurso: os meios jornalistico e acadêmico (DALCASTAGNÉ, 2012, p. 14).

Seria possivel refutar a constatação de Dalcastagné atacando o conceito restritivo de literatura com o qual estamos (tanto ela, quanto eu) operando para advogar que, da vasta gama de herdeiros digitais dos folhetins, dos blogs, dos zines, do cordel, e também da tradição oral, do slam e da música popular, sopram ventos benfazejos ao repertório cultural brasileiro. Mas é preciso reconhecer que literatura, na primeira acepção dos dicionários, remete ao "uso estético da linguagem escrita" (HOUAISS, 2009) e que os estudos literários (como campo acadêmico) pautam-se majoritariamente por textos publicados, ou seja, por impressos feitos para serem entregues a um público (HOUAISS, 2009), geralmente livros. Essa é a perspectiva da qual parto não para refratar os influxos que as margens - uso o termo conforme a abordagem polissistêmica (EVENZOHAR, [1978] 2013) - exercem sobre o centro do (polis)sistema, mas justamente para criticar a rigidez desse centro, determinado e protegido por nosso repertório conservador:

Quando se estabelece um repertório e todos seus modelos derivados se constroem de completo acordo com o que permite, nos depararmos com um repertório (e sistema) conservador. Qualquer produto individual (enunciado, texto) será então altamente previsivel, e qualquer desvio será considerado escandaloso (EVEN-ZOHAR, [1978] 2013, p. 13).

No entanto, a desacomodação do centro de um sistema imerso em crises poetológicas pode provir da literatura em tradução, que exerce forças inovadoras ("primárias") se traz consigo modelos aptos a romper com a previsibilidade dos produtos da literatura-alvo.

Analisando a contemporaneidade, Marie Helene Catherine Torres (2009) estima que cerca de $70 \%$ das traduções circulantes no mundo é composta pelos chamados best-sellers, livros concebidos a partir de uma sintaxe linear e vocabulário propositadamente simples para facilitar a tradução rápida a vários idiomas. Planejadas para a comercialização massiva em culturas dispares, essas literaturas são construidas a partir de estereótipos e dilemas existenciais de tendências moralizantes. Portanto, têm o objetivo de conservar, e não de desacomodar os repertórios que as recebem. O consumo amplo desses produtos pode ser explicado pela ânsia das culturas colonizadas por compartilhar as visões metropolitanas:

\footnotetext{
Os best-sellers do primeiro mundo são lançados na mesma semana no New York Times, e reproduzidos no caderno Ideias do Jornal do Brasil, no Prosa e Verso de O Globo e na Folha de S. Paulo e no Estado de São Paulo. Essa simultaneidade visa a produzir no leitor a sensação de pertencer àquele mundo, e a facilitar a aceitação, massificação e comercialização dos produtos culturais importados (WYLER, 2003, p. 18).
} 
Os produtos concebidos para o consumo de massa mudam a relação do sistema receptor da tradução com a cultura de dominação. Segundo Javier Franco Aixelá:

A importação constante de itens de consumo (cultural e outros) da América de língua inglesa não implica somente em uma familiaridade crescente de diversas sociedades com a visão anglo-saxônica, mas também em um claro processo de aceitabilidade de seus valores e realidade cultural especifica. Além disso, estabelece uma série de estratégias de tradução que mais tarde é mimeticamente aplicada em textos de outras áreas culturais (AIXELÁ, [1996] 2013, p. 188).

Por esse fenômeno, segundo Aixelá ([1996] 2013), itens que antes eram considerados especíicos da cultura traduzida deixam de sê-lo. À guisa de exemplo, Aixelá, analisando as traduções de $O$ Falcão Maltês para o espanhol europeu, constata que "a versão de 1933 oferece um termo esportivo como golf em itálico, destacando sua natureza exótica [...]; já as versões de 1967 e 1992 repetem o termo sem nenhuma marca tipográfica" (AIXELÁ, [1996] 2013, p. 189-190), indicando que o termo, antes especíico da língua-cultura-fonte, está sendo absorvido pela lingua-cultura-alvo mediante a exposição continuada. Essa hegemonia do sistema exportador pelo sistema importador explica a tendência à "aceitabilidade máxima" de elementos da cultura provedora na cultura receptora, pois esta pretende ler a tradução como se fosse o original, rechaçando a naturalização de elementos externos para atender a normas internas. Assim, a tradução de nomes próprios (Mary - Maria) e a adaptação ortográfica de estrangeirismos (shampoo - xampu) têm sido recursos cada vez menos empregados por tradutores/as que lidam com textos provenientes da língua inglesa.

O interesse por traduções de narrativas da lingua inglesa e a naturalização entre nós de vocabulário dela proveniente acentua-se no século XX, no encalço da Segunda Guerra. A Revista do Globo, da editora homônima, de Porto Alegre, traz, em 1940, noticias do front, ao mesmo tempo em que anuncia a tradução para o português dos livros de maior sucesso recente no estrangeiro. Sob essa influência e das rápidas e drásticas transformações do pós- guerra, as mulheres começam a ser traduzidas no Brasil - mas não todas. Felicidade, de Katherine Mansfield, é lançado em livro com tradução de Erico Verissimo, em 1940. Antes disso, seis contos dela já tinham sido publicados em $A$ Novela, outra revista vinculada à editora Globo (BOTTMANN, 2016). Virginia Woolf é lançada pela Globo, em traduções de Mario Quintana (Mrs Dalloway, 1946) e Cecilia Meirelles (Orlando, 1947), em circulação até hoje. Nesse periodo, ganham espaço as tradutoras. Oliveira (2015) elenca 102 mulheres, incumbidas de traduzir, nas décadas de 1930 e 1940, sobretudo obras de outras mulheres: "dos 161 autores [de lingua inglesa] cujas obras foram traduzidas [por mulheres], 85 (53\%) eram do sexo feminino" (OLIVEIRA, 2015, p. 135), o que pode ser explicado pela ascensão de um público leitor feminino. A única hispano-americana publicada no Brasil, segundo a listagem de Karam (2016), é María Luisa Bombal. Ocorre que o livro lançado pela editora Irmãos Pongetti, em 1949, é uma tradução (do inglês) assinada por Carlos Lacerda da obra House of mist (KAHMANN, 2018). Assim, em que pese Bombal ter nascido no Chile, é possivel deduzir que ela não teria circulado no Brasil se não fosse via Estados Unidos.

Gayatri Chakravorty Spivak, a propósito, recorda:

Às vezes leio e ouço que o subalterno pode
falar em suas linguas nativas. Eu gostaria de
poder ter essa autoconfiança tão firme e inaba-
lável que têm o intelectual, o crítico literário e
o historiador que, aliás, afirmam isso em inglês.
Nenhuma fala é fala enquanto não é ouvida.
([2000] 2005, p. 58).

Eliana de Souza Ávila (2013), em Pode o tradutor ouvir?, constituido a partir da obra de Spivak Pode o subalterno falar?, invoca a capacidade do/a tradutor/a (e, por extensão, o/a pesquisador/a em tradução) de refletir sobre a missão de falar pelo/a e para o/a subalterno/a. O imperativo ético da tradução, portanto, consiste em reconhecer que não basta o/a subalterno/a falar se não houver tradutor/a apto/a a ouvirpara-responder e, assim, romper com opressões como as impostas pelas estruturas coloniais que são discutidas a seguir. 


\section{Traduzir para decolonizar}

Susan Bassnett, para quem a história da tradução é central em todo estudo literário comparativo, afirma que é impossivel estabelecer qualquer critica literária sem levar em consideração "a desigualdade das relações de poder que caracterizam o processo de tradução" (BASSNETT, [1980] 2003, p. 7). Com efeito, mudam os métodos e os instrumentos de dominação; mudam as tecnologias de constrangimentos e recompensas, que a alguns seres humanos autorizam a voz e a outros silenciam, seja pela força bruta, seja por restrições simbólicas. Contudo, a pesquisa em literatura tem por missão questionar essa linha a separar quem pode clamar de quem deve calar, e a tradução (se pretender-se libertária) deve-se comprometer com dar voz à pessoa subalternizada, em vez de reforçar a dominante.

Boaventura de Sousa Santos (2010) designa pensamento abissal a esse sistema de conformação de valores calcado em distinções visiveis e invisiveis, em que essas fundamentam aquelas, dividindo a realidade social em dois universos distintos, negada a possibilidade de copresença nos dois lados. Visto da perspectiva do/a colonizado/a, do lado de lá dessa linha, estão as sociedades metropolitanas (colonizadoras); aqui, os seres humanos e territórios dominados (colonizados). Do lado de cá da linha abissal, não há voz possivel, até porque não há nada (relevante) a dizer. Aqui não se observa conhecimento real; só existem "crenças, opiniões, magia, idolatria, entendimentos intuitivos e subjetivos que, na melhor das hipóteses, podem tornarse objetos ou matéria-prima para a inquirição científica" (SANTOS, 2010, p. 34). Tão imponente é o pensamento abissal que, embora Anibal Quijano ([2005] 2014) recorde que as grandes vias de transporte, a agropecuária, o calendário, a matemática, as tecnologias metaliferas, a filosofia, a história, as línguas e as literaturas provêm de muito antes da formação da Europa e do europeu, a modernidade, a racionalidade, e mesmo a arte, são compreendidas como patrimônios fundados pela (se não exclusivos da) cultura colonizadora.

As independências dos paises da América, havidas às custas da dizimação dos povos originários, não põem em xeque esse pensamento abissal; apenas o reconfiguram de modo a seguir ditando "linhas abissais que dividem o mundo humano do sub-humano" (SANTOS, 2010, p. 39). Nessa divisão, construtos como raça e gênero conformam complexas hierarquias de dominação que consolidam elementos como masculinidade e branquitude como sendo os principais canais de atribuição de valor e prestígio.

Quijano ([2005] 2014) argumenta que valorações de dominação e inferioridade conforme padrões fenotipicos não ocorriam antes da dominação dos povos amerindios (e, posteriormente, dos africanos, para a manutenção da estrutura colonial). Com a consolidação do capitalismo e a sofisticação dos mecanismos de exploração e controle da produção-apropriação-distribuição dos produtos, raça e divisão de trabalho passam a reforçar-se mutuamente. Disso, advém uma nova tecnologia de dominação/exploração, articulada de tal maneira a parecer natural e, por isso, extraordinária, pois é incontestável. Constitui-se o que Quijano ([2005] 2014) designa id-entidade. Esse conceito contém em si três elementos fundamentais para se compreender a colonização: identidade (um eu que se opõe a outros no mundo), entidade (como sociedade, instituição ou, ainda, objeto de culto) e id, que, segundo a teoria freudiana, evoca o inconsciente mais bruto, com o seu lado hereditário, irrefletido, pulsional, mas recalcado. Embora concebido para explicar as tensões raciais decorrentes das estruturas coloniais, o construto de id-entidade pode amparar também as subalternizações em função de gênero.

As condições das mulheres nesta América que hoje se designa Latina são intrinsecamente marcadas pelas linhas abissais inerentes à colonização, até porque o construto raça não discrimina sexo e, ao determinar o que é corpo e não corpo, quem tem alma e quem não a tem, o processo de colonização viola sistematicamente a liberdade, a integridade fisica, a dignidade e a vida tanto de homens quanto de mulheres. Entre as violências típicas da conquista das Américas está o sequestro de autóctones para a sua 
transformação em intérpretes (ou línguas, como se chamavam então) a serviço da espoliação. Na cultura espanhola, La Malinche (Malintzin ou Malinalli, em náhuatl), escravizada convertida em intérprete e amante de Hernán Cortés, transforma-se em sinônimo de traição grafado no Diccionario de la Real Academia Española.

Apesar de La Malinche encarnar a metáfora perfeita da indigena violada pelo colonizador e, ao mesmo tempo, da traição contra seu povo, Roberto A. Valderón (2014) recorda que as mesmas violências recebem narrativas diversas na cultura anglo-americana. A falácia de que a conquista da América do Norte é mais branda (porque motivada pela busca de um "lar") se apropria de imagens como a de Pocahontas, uma indigena que, por amizade, aprende a língua dos/ as conquistadores/as e, ao fim, casa-se com um europeu (passando-se ao largo de seu sequestro e do enlace matrimonial forçado). Enquanto La Malinche se torna sinônimo de traição na América espanhola, faz-se de Pocahontas um símbolo de integração da América inglesa.

A tradução (linguística ou cultural) exerce um papel crucial na construção dos impérios e pode ser analisada, na perspectiva contemporânea, como metáfora sexual. De acordo com Antoine Berman ([1995] 2002), quando a língua ingressa no rol de riquezas inventadas por um determinado Estado nacional, popularizam-se metáforas de conotação sexual. Uma língua que não traduz é comparada a uma moça virgem; de uma língua que traduz se diz que é fecundada pelo estrangeiro. "Pouco importa que, no nível da realidade, uma cultura e uma língua virgens sejam tão fictícias quanto uma raça pura. Trata-se aqui de desejos inconscientes" (BERMAN, [1995] 2002, p. 17). O uso da língua como instrumento de dominação e a desconfiança frente às malinches que traduzem (e miscigenam) permanecem até hoje na linguagem literária e acadêmica em aforismos como traduttore traditore e belle infidèlle, que associam tradução à traição, mas uma traição feminina, a serviço de uma conquista masculina.

Na história do Brasil, a subalternização das mulheres relaciona-se ao processo de colonização.
Embora o padre Manuel da Nóbrega tenha feito chegar à rainha Catarina os apelos dos indigenas para que se fundassem escolas também para as meninas - "uma extravagância que ainda não entrara nas cogitações nem do mais ilustrado renascentista" (WYLER, 2003, p. 54) - às mulheres se lhes nega o acesso ao letramento mais básico até o século XIX. Conforme Laurence Hallewell: "Apenas na década de 1820 - e muito mais tarde nas províncias -, o analfabetismo feminino deixou de ser encarado como um sinal de nobreza: esse traço era tido como uma contribuição essencial à moralidade" ([1975] 2012, p. 175).

Peter Burke refere que, nos primórdios da Europa Moderna, as mulheres eram relativamente proeminentes como tradutoras - "provavelmente porque a tradução era considerada mais compativel com a modéstia feminina do que a escrita original" ([2007] 2009, p. 18) - e, também, como patronas de traduções - à guisa de exemplo: "John Florio dedicou as três primeiras partes de sua tradução dos Ensaios, de Montaigne, (1603) a seis mulheres da nobreza" (BURKE, [2007] 2009, p. 22). No Brasil, porém, somente quando as primeiras brasileiras aprendem a ler e adquirem consciência do estatuto de exceção que ocupam ante aquela sociedade, surgem as primeiras traduções de e para mulheres, comprometidas, sobretudo, com a ampliação de direitos - primeiramente, buscando acesso à educação; depois, à profissão e ao voto. Conforme Constância Lima Duarte:

\begin{abstract}
A primeira legislação autorizando a abertura de escolas públicas femininas data de 1827, e até então as opções eram uns poucos conventos. que guardavam as meninas para o casamento, raras escolas particulares nas casas das professoras, ou o ensino individualizado, todos se ocupando apenas com as prendas domésticas. E foram aquelas primeiras (e poucas) mulheres que tiveram uma educação diferenciada, que tomaram para si a tarefa de estender as benesses do conhecimento às demais companheiras, e abriram escolas, publicaram livros, enfrentaram a opinião corrente que dizia que mulher não necessitava saber ler nem escrever (DUARTE, 2003, p. 153).
\end{abstract}

Nesse ambiente em que as mulheres começam a acessar ao mais básico dos direitos, a tradução 
presta-se também à defesa de sua ignorância: em 1830, um ex-seminarista pernambucano traduz a obra Da educação das meninas (FERREIRA, 2003, p. 126), do bispo François Salignac de La Mothe Fénelon (1651-1715). Publicada pela primeira vez em 1687 e escrita "por solicitação do duque de Beauvilliers, da corte de Luís 14 e encarregado de organizar a educação do príncipe herdeiro, que tinha uma familia numerosa e, essencialmente, composta de mulheres" (BASTOS, 2012, p. 148), essa obra é posta em circulação no Brasil quase dois séculos depois de sua concepção em uma França que já havia cambiado absurdamente. Nesses escritos, feitos para o uso privado, consta que "é o cérebro das meninas qual vela acessa em sítio exposto ao vento: sua luz vacila sempre" (BASTOS, 2012, p. 165) e, assim, não deve ser exposto a matérias que exigem reflexão (como a filosofia) nem perder tempo com artes que incitam ao devaneio (como a poesia e música).

Mas esse periodo vê nascer, ademais, "o texto fundante do feminismo brasileiro" (DUARTE, 2003, p. 153). A obra de Nisia Floresta Brasileira Augusta, pseudônimo de Dionísia Gonçalves Pinto (1810-1885), impressa em Recife em 1832. sob o título Direito das mulheres e injustiça dos homens, apresenta-se como uma "tradução livre" de Vindication of the rights of women, de Mary Wollstonecraft Godwin (HALLEWELL, [1975] 2012), mas traz trechos de Poulain de la Barre, de "Sophia, uma pessoa de qualidade" (Woman is not inferior to Man, de 1739) e artigos da Declaração dos Direitos da Mulher e da Cidadã, de Olympe de Gouges (DUARTE, 2003). Apesar disso, é considerada uma nova escritura (ainda que inspirada na leitura de outras), pois se constitui uma resposta brasileira ao escrito inglês. Nisia Floresta argumenta, nessa obra, que as desigualdades provêm das restrições à educação e das condições de vida impostas às mulheres em função da herança portuguesa. Trata-se, portanto, de uma tradução cultural, ou seja: não da letra, mas uma "antropofagia libertária" (DUARTE, 2003, p. 154), com a "nossa autora se colocando em pé de igualdade com a Wollstonecraft e o pensamento europeu, e cumprindo o importante papel de elo entre as ideias estrangeiras e a realidade nacional" (DUARTE, 2003, p. 153).

Portanto, é possivel argumentar, com Constância Lima Duarte, que a tradução é a principal propulsora do feminismo entre nós, pois:

[...] a nossa primeira onda [do feminismo], mais
que todas as outras, vem de fora, de além
mar, não nasce entre nós. E Nisia Floresta é
importante principalmente por ter colocado
em língua portuguesa o clamor que vinha da
Europa, e feito a tradução cultural das novas
ideias para o contexto nacional, pensando
na mulher e na história brasileira (DUARTE,
2003, p. 154).

Segundo Constância Lima Duarte (2003), a leitura de Nisia Floresta (republicada em Porto Alegre, em 1833) inspira, entre outras, a gaúcha Ana Euridice Eufrosina de Barandas e o seu livro A philosopha por amor (1845), no qual defende a capacidade das mulheres para os estudos, para opinar sobre os rumos da nação e exercer profissões e cargos de comando. Muitas são as seguidoras na promoção de significativas mudanças ao longo dos séculos XIX e XX, confirmando que periodos de grandes inovações literárias são precedidos por intensa atividade tradutória (BASSNETT, [1980] 2006). No plano individual, Oliveira (2015) postula que a tradução serve também de porta de entrada para muitas mulheres no mundo das letras (a exemplo de Nísia Floresta), permite subsistência econômica (Rachel de Queiroz) e contribui para a formação de uma identidade autoral (Ana Cristina Cesar). Por essas (e outras) razões, os estudos da tradução tendem a crescer em relevância para os estudos feministas.

\section{Projetos e vazios tradutórios de escritoras hispano-americanas}

O Brasil ingressa no século XX majoritariamente analfabeto, incluindo nessa categorização amplas camadas de proprietários de terras e setores identificados como elites (CARVALHO, 2002). É somente no Censo de 1960 que o IBGE constata, pela primeira vez, haver mais pessoas com capacidade de ler do que analfabetas. Apesar dos rápidos avanços nos indicadores demográficos do Brasil alcançados ao longo 
do século $X X$, o analfabetismo entre pessoas com dez anos ou mais de idade, no segundo trimestre de 2017 (IBGE, 2018b), aponta para $6,5 \%$ do universo populacional. À guisa de comparação com o outro extremo das estatísticas de letramento na realidade latino-americana: "em meados da 1930, os analfabetos nativos de Buenos Aires representavam apenas 2,39\% num total de 6,64\%" (SARLO, [1988] 2010, p. 39). O alto padrão de letramento da capital argentina possibilita que ali se estabeleçam, já na década de 1930, as precondições para a consolidação de um mercado editorial local voltado para um público leitor potencial "não apenas nas camadas médias, mas também de setores populares" (SARLO, [1988] 2010, p. 39). Passa-se a produzir uma literatura diferenciada, potencializada pela ampla atividade tradutória.

No entanto, apesar da literatura inovadora que vinha sendo produzida em Buenos Aires desde 1930, é somente após o chamado boom da literatura latino-americana, na década de 1970, quando "nenhum leitor sério de romances podia [...] ter deixado de entrar em contato com a brilhante escola de escritores latino-americanos" (HOBSBAWM, [1994] 1995, p. 485), que o mercado editorial brasileiro se volta para os países vizinhos de língua tão próxima. Em 1969, publica-se no Brasil o primeiro livro do (hoje) canonizado Jorge Luis Borges: Nova antologia pessoal, pela editora Sabiá, do Rio de Janeiro (KARAM, 2016). Em 1970, o (hoje) célebre Ficções, a tradução de Carlos Nejar para Ficciones (1944), sai pela Editora Globo, de Porto Alegre. Está aberto o caminho para a consagração de Borges (também) no Brasil. A partir do levantamento de autores/as de origem hispano-americana traduzidos/as no Brasil realizado por Karam (2016), chega-se ao montante de 59 títulos ostentando o nome de Jorge Luis Borges como autor, coautor, ou compilador 4 .

No entanto, se é indiscutivel que Borges, para adentrar no "mercado editorial brasileiro, necessitou, primeiramente, ser reconhecido pelo eixo euro-norte-americano" (VALLERIUS, 2010, p. 222), a consagração externa não traz a mesma sorte à chilena Gabriela Mistral. Agraciada com o prêmio Nobel em 1945, ela recebe apenas uma publicação como única autora no Brasil, conforme o levantamento de Marlova Aseff (2016): sob o título Poesias escolhidas, a tradução de Henriqueta Lisboa para a coleção Prêmios Nobel de Literatura da editora Delta, é publicada em 1964.

Seria possivel atribuir à dificuldade de se traduzir poesia o empecilho para a circulação dos versos de Mistral no Brasil. Não obstante, em 2014, o catálogo completo da Coleção L\&PM Pocket, disponivel para download no site da L\&PM em arquivo Portable Document Format (PDF), com 448 páginas, apresenta mais de mil títulos listados, dos quais 687 são apresentados como literatura. Desses, 478 são traduções (69,6\%), das quais 39 provém do idioma espanhol (pouco mais de $8 \%$ do total de traduções). Dentre as 39 obras literárias traduzidas do espanhol, somente Pablo Neruda responde por 15 títulos. O fato de o também prêmio Nobel chileno representar quase $40 \%$ do catálogo proveniente da língua espanhola da mais popular coleção de livros econômicos circulante no Brasil parece lançar por terra o argumento de que é a escolha pela poesia que relega Mistral a um quaseostracismo. Ademais, cabe apontar que, embora tenha veiculado muitas mulheres (brasileiras e em tradução), a coleção L\&PM Pocket, em 2014 , não apresenta nenhum título, seja de prosa ou de poesia, em tradução proveniente do idioma espanhol (europeu ou nas diversas variantes latinoamericanas) de autoria feminina.

Sobre a fama literária de Gabriela Mistral, é necessário recordar que, em sua pátria natal, o Chile, ela só recebe o Prêmio Nacional de Literatura seis anos após a unção pelo Prêmio Nobel. Também na civilizada Buenos Aires, a lírica intimista de Mistral desperta ojeriza de contemporâneos do sexo masculino. O capítulo que Beatriz Sarlo intitula "Dizer e não dizer: erotismo e repressão" tem início com uma epígrafe do polemista Raúl González Tuñón:

\footnotetext{
4 Ai inclusas as publicações com Bioy Casares, Adolfo sob o pseudônimo de H. Bustos Domecq, e correspondências, como em Diálogos Borges Sabato, entre Jorge Luis Borges e Ernesto Sabato.
} 
Te quero, oh, minha perfeita ignorante!

Não conheces Keyserling e ignoras o volume da terra - para falar a verdade, senhores, eu também. Nem sequer leste Tagore, Mistral ou Nervo, esses idolos das mulheres que não sabem beijar, nem fazer crochê, e, para nosso mal, escrevem versos (apud SARLO [1988] 2010, p. 127, grifos meus).

Com efeito, muito mais que as desconfianças que o Brasil (por heranças coloniais, por disputas de fronteiras) possa nutrir em relação aos vizinhos da América Latina, e muito mais que a colonialidade do pensamento que nos induza a importar preponderantemente produtos da cultura dominante (desde a Segunda Guerra, a de língua inglesa), o gênero de quem escreve também é um fator a ser considerado no ancoramento da recepção. Consultando a tabela anexa à pesquisa de Karam (2016), dedicada apenas a obras hispano-americanas publicadas no Brasil, identifico 59 autoras ${ }^{5}$ de obras de e sobre literatura publicadas entre 1920 a 2016. Trata-se de um número relevante, mas que representa menos de 20\% do universo de 305 autores/as ${ }^{6}$ de 1.062 títulos catalogados.

A baixa receptividade brasileira à literatura de mulheres hispano-americanas em tradução pode indicar que, em nossos resquícios abissais, concedemos à autoria o direito de apresentar apenas uma das seguintes variáveis vulnerabilizatórias: ou ser mulher, ou ser da América de língua espanhola. Ser mulher e ainda hispano-americana, ou seja, duas vezes subalternizada, é demais para nossas estruturas colonizantes e patriarcais, que, apesar disso, se aferram à defesa da existência de um tal de mérito literário para explicar essa realidade.
A instituição universitária, com professores/ as, criticos/as, comentadores/as e reescritores/ as, vem desempenhando o relevante papel de apontar essas lacunas, e também de preenchêlas. Como exemplo, o número especial Autoras latino-americanas traduzidas para o português, dos Cadernos de Literatura em Tradução, da Universidade de São Paulo, traz, na introdução, dedicada a Marielle Franco, a seguinte constatação:

A cubana Gertrudis Gómez de Avellaneda (18141873) debateu sobre a escravidão no romance Sab (Madrid, 1841; Cuba, 1914), publicado dez anos antes do romance $A$ Cabana do Pai Tomás (Uncle Tom's Cabin, 1851), de Harriet Beecher Stowe, sobre a escravidão nos Estados Unidos (GUARDIA, 2007). Sab nunca foi traduzido no Brasil, ao passo que A Cabana do Pai Tomás chegou ao pais nos folhetins em 1887, a partir de uma edição parisiense, e em formato livro em 1893, traduzido por Cândido de Magalhaes (FERRETI, 2017) (SILVA; BEZERRA, 2019, p. 8).

Com efeito, no levantamento de Karam (2016) sobre edições comerciais, não consta nenhuma obra de Gertrudis de Avellaneda. Apesar de sua relevância abolicionista comparável à obra Úrsula, de Maria Firmina dos Reis (ANDRETA, 2016), Sab segue sem tradução ao português. Esse vazio tradutório diz mais sobre os melindres brasileiros ante as mulheres de ideias do século XIX que sobre o mérito da obra, que pode ser consultada em tradução para o inglês.?

De Juana Manuela Gorriti (1818-1892), escritora argentina que peregrina por terras bolivianas e peruanas, a editora paulista Liber Ars publica, em 2017, a coletânea Contos de Juana Manuela Gorriti, de um grupo de tradução vinculado à Universidade Federal do Rio Grande (FURG), sob a organização e supervisão das professoras

\footnotetext{
5 São elas: Aguirre, Isidora; Allende, Isabel; Almada, Selva; Arana, Marie; Bellessi, Diana; Belli, Gioconda; Berman, Sabina; Besouchet, Lídia; Bird, Poldy; Bombal, MariaLuisa; Bornemann, Elsa Isabel; Bortagaray, Inés; Brizuela, Natalia; Bullrich, Silvina; Burundarena, Maitena; Calveiro, Pilar; Canto, Estela; Da Silva, Carmen; Dujovne Ortiz, Alicia; Esquivel, Laura; Garramuño, Florencia; Guerra, Wendy; Guido, Beatriz; Iparraguirre, Sylvia; Kamenszain, Tamara; Kaufmann, Paola; Lange, Norah; Ludmer, Josefina; Luiselli, Valeria; Lynch, Marta; Mastretta, Ángeles; Mercado, Tununa; Meruane, Lina; Molloy, Sylvia; Montero, Mayra; Moreno, María; Nettel, Guadalupe; Oloixarac, Pola; Osorio, Elsa; Piñeiro, Claudia; Pizarnik, Alejandra; Poniatowska, Elena; Puenzo, Lucia; Restrepo, Laura; Reyes, Emma; Rivera Garza, Cristina; Saguier, Raquel; Sarlo, Beatriz; Scheuber, Yolanda; Schweblin, Samanta; Sefchovich, Sara; Serrano, Marcela; Shua, Ana Maria; Torres Molina, Susana; Traba, Marta; Valdés, Zoé; Valenzuela, Luisa; Vázquez, Maria Ester; Verdugo, Patricia. Sendo interesse desta pesquisa rastrear obras de autoria feminina, não computei entre esses 59 nomes as coautorias ou organizações de mulheres em companhia de homens renomados. Foram excluídas, portanto: Antologia da literatura fantástica, de Bioy Casares, Adolfo, Borges, Jorge Luis e Ocampo, Silvina; O livro dos seres imaginários e O Martín Fierro, de Borges, Jorge Luis e Guerrero, Margarita; Buda, de Borges, Jorge Luis e Jurado, Alicia, Atlas, de Borges, Jorge Luis e Kodama, María, bem como Os autonautas da cosmopista, de Cortázar, Julio e Dunlop, Carol (cf. KARAM, 2016 - tabela: livros de autores hispano-americanos publicados no Brasil).

6 Computados apenas os/as primeiros/as autores/as de cada obra. Além desses 305 nomes, Karam (2016) levantou 21 coletâneas, com vários/as autores/as.

7 A tradução de Nina Scott pode ser acessada em: http://faculty.csuci.edu/stephen.clark/SabEnglish.pdf. Acesso em: 20 out. 2019.
} 
Daniele Corbetta Piletti e Joselma Noal e do professor Artur Emilio Alarcon Vaz. Antes disso, porém, em 2013, o conto A luva negra é publicado na revista Mafuá (UFSC) em tradução de Cecilia de Souza Borba, e Peregrinaciones de un alma triste recebe tradução comentada na dissertação de mestrado de Andreza Aparecida Gomes de Andrade (Unesp).

A peruana Clorinda Matto de Turner, pseudônimo de Grimanesa Martina Matto Usandivaras de Turner (1852-1909), é reconhecida por trazer à luz a questão indigena, a discriminação racial e os abusos das elites. Aves sin nido (1889) "llegó a ser, sin exagerar, la novela más leída y comentada de su época" (FERREIRA, [2019]). Não há (ainda) tradução completa circulante dessa obra, embora o capítulo IV de Aves sin nido esteja disponivel em tradução de Roseli Barros Cunha (2017) na revista Transversal (UFC). Das narrativas curtas de Clorinda, As duas partidas, em tradução de Laura Paola Ramos Alves (2018), está publicada nos Cadernos de Tradução da UFRGS. Carecem ainda de publicação em português as novelas indole (1891) e Herencia (1895), bem como os seus relatos curtos de ficção histórica que, seguindo a esteira de Ricardo Palma, têm por objetivo criar narrativas genuinamente peruanas, dialogando com heranças indígenas e do periodo colonial.

Outras precursoras na ruptura da hegemonia masculina nas letras são citadas por Sara Guardia (2013): Mercedes Cabello de Carbonera (Peru, 1845-1909), Lindaura Anzoátegui (Bolivia, 1846-1898) e Adélia Zamudio (Bolivia, 18541928). Relegadas às margens dos sistemas de consagração, as obras dessas escritoras outorgam voz a pessoas desvalidas, "questionando as relações inter-raciais e de classe" (GUARDIA, 2013, p. 18). No rol das precursoras da literatura hispano-americana, elas têm a companhia de María Josefa Acevedo de Gómez (Colômbia, 1803-1861), Juana Manso (Argentina, 1819-1875), Eduarda Mansilla (Argentina, 1834-1892), Rosario Orrego (Chile, 1834-1879), Teresa González del Real de Fanning (Peru, 1836-1918), Polita de Lima Salcedo (Venezuela, 1869-1904), Laura Méndez de Cuenca (México, 1853-1928), Alfonsina Storni (Argentina, 1892-1938), María Nieves y Bustamante
(Peru, 1861-1947), María Luisa Ocampo Heredia (México, 1905-1947) para se estar apenas com autoras em domínio público.

Além dos esforços nascidos na academia, há de se reconhecer as iniciativas publicadas por editoras independentes. De Teresa de la Parra, como ficou conhecida no mundo literário Ana Teresa Parra Sanoja (1889-1936), venezuelana nascida em Paris, a editora Carambaia publica, em 2016, em tradução de Tamara Sender, Ifigênia (de 1928), considerada uma obra emblemática do feminismo latino-americano. Em 2019, a editora Arte e Letra lança Três objetos, coleção de contos de la Parra em tradução de lara Tizzot. Até o momento, porém, desconheço, tradução para Memorias de Mamá Blanca, considerado, por Victor Bravo (2008), um dos livros-chave da narrativa venezuelana.

No que tange à poesia, Alguns cálices d'Os Cálices Vazios, tradução de Gleiton Lentz (2007) a poemas da uruguaia Delmira Agustini (1886-1914), vítima de feminicidio após conceber os versos mais erotizados de sua época, está publicada em Cadernos de Literatura em Tradução (USP). Gleiton Lentz é também o tradutor do livro de autoria única de Agustini publicado em edição bilingue em 2005 pelas Edições Nephelibata, de Florianópolis (ASEFF, 2016).

(Sóror) Juana Inés de la Cruz (México, 16511695), transformada em série pela plataforma de streaming Netflix (2016), tampouco tem um livro de autoria única circulante no Brasil, mas integra três coletâneas, segundo Aseff (2016), e vem recebendo traduções acadêmicas, como Tradução comentada da peça teatral Amor es más laberinto de Sor Juana Inés de la Cruz, tese doutoral de Mara Gonzalez Bezerra (2016). Dois de seus sonetos foram traduzidos por Nathaly Nalerio Gomes (UFPel): Esta tarde, meu bem, quando eu falava e Rosa divina que em gentil cultura (GOMES, 2018).

Nessa breve lista de "vazios tradutórios" tenho o cuidado de indicar apenas autoras hispanoamericanas em domínio público (art. 41, Lei 9.610/98), ou seja, aquelas para as quais não existem obstáculos à tradução/publicação/ circulação salvo a sua condição de invisibilidade. 
Assim, e relembrando a exortação de Ortega y Gasset, para quem todo/a escritor/a "deveria não menosprezar a ocupação de traduzir e complementar sua obra pessoal com alguma versão do antigo, medieval ou contemporâneo" ([1937] 2013, p. 46), conclamo a todas mis hermanas (re)escritoras à antropofagia da tradução. Devoremo-nos, alimentemo-nos da fortaleza de quem, como nós, enfrenta o pensamento colonial/patriarcal/abissal e assumamos o imperativo ético de traduzir-para-fazer-ouvir.

\section{Considerações finais}

Apesar de reconhecer o incremento de circulação de narrativas de mulheres hispanoamericanas (sobretudo as contemporâneas) em tradução no Brasil, este artigo finaliza elencando algumas autoras e obras em domínio público, como uma exortação à sua tradução. Além do postulado benjaminiano de que a tradução sempre eleva o seu original, deixando entrever um novo aspecto que o enriquece (BENJAMIN, [1923] 2008), ou seja, indicando um "ganho" para o original, há, em toda tradução, um exercício de alteridade, um deslocar(-se) entre o próprio e o alheio (CARVALHAL, 2003), um (re)conhecimento entre o que em uma língua-cultura é possivel dizer e o que não se é sequer capaz de formular. Uma tradução é, portanto, "a revelação dos segredos mútuos que povos e épocas guardam reciprocamente e tanto contribuem para a sua dispersão e sua hostilidade; em suma, uma audaciosa integração da Humanidade" (ORTEGA Y GASSET, [1937] 2013. p. 29). Assim, em tempos que a humanidade eleva o tom dos nacionalismos, levanta muros e clama por novas exclusões, proponho um esforço sistemático de tradução de literatura de mulheres hispano-americanas, entendendo que, entre nós, na especificidade latino-americana, "o feminismo não seja uma questão individual, mas de justiça social e democratização da sociedade" (NAVARRO, 1997, p. 46), pois é impossivel de ser desvinculado das lutas sociais e das questões politicas. E, por isso, tão relevante na desestabilização desse cânone de perspectiva única.

\section{Referências}

AIXELÁ, Javier Franco. Itens culturais-específicos em tradução. Tradução de Mayara Matsu Marinho e Roseni Silva. In-Traduções, Florianópolis, v. 5, n. 8, p. 185-218, jan./jun., 2013. Disponivel em: http://incubadora.periodicos.ufsc.br/index.php/intraducoes/ article/viewFile/2119/2996. Acesso em: 26 jul. 2019 https://doi.org/10.5007/2175-7968.2019v39n2p116

ALVES, Laura Paola Ramos. As duas partidas (Clorinda Matto de Turner). Cadernos de Tradução (do Instituto de Letras da UFRGS), Porto Alegre, n. 42, p. 62-67, jan./jul. 2018. Disponivel em: https://seer.ufrgs.br/cadernosdetraducao/article/ view/83002. Acesso em: 29 jul. 2019. https://doi. org/10.22456/2236-6385.22837

ANDRADE, Andreza Aparecida Gomes de. Tradução comentada de Peregrinaciones de una alma triste de Juana Manuela Gorriti. Dissertação de Mestrado Faculdade de Ciências e Letras de Assis - Universidade Estadual Paulista, 2013. 287f. Disponível em:

https://repositorio.unesp.br/bitstream/handle/11449/113798/000796912.pdf. Acesso em: 29 jul. 2019. https://doi.org/10.33582/2637-4900/1011

ANDRETA, Bárbara Loureiro. Visões da escravatura na América Latina: Sab e Úrsula. Dissertação (mestrado). Universidade Federal de Santa Maria, Programa de Pós-Graduação em Letras, 2016. $150 f$. Disponivel em: https://repositorio.ufsm.br/handle/1/12081. Acesso em: 15 out. 2019. https://doi. org/10.18226/610001/mostraxvi.2016.45

ASEFF, Marlova. Poesia Traduzida no Brasil. Brasilia, 2016. Disponivel em: https://poesiatraduzida.com.br. Acesso em: 29 jul. 2019.

ÁVILA, Eliana de Souza. Pode o tradutor ouvir? In: BLUME, Rosvitha Friesen; PETERLE, Patricia (org). Tradução e relações de poder. Tubarão: Ed. Copiart; Florianópolis: PGET: UFSC, 2013. p. 21-68.

BASSNETT, Susan. Estudos de tradução: fundamentos de uma disciplina. Tradução de Vivina de Campos Figueiredo. Lisboa: Fundação Calouste Gulbenkian, 2003.

BASSNETT, Susan. Reflections on Comparative Literature in the Twenty-First Century. Discurso para a Associação Britânica de Literatura Comparada. Comparative Critical Studies, [S. l.], v. 3. n. 3, p. 3-11, 2006. Disponivel em: http://muse.jhu.edu/journals/ comparative_critical_studies/v003/3.1bassnett.html. Acesso em: 28 set. 2015. https://doi.org/10.1353/ccs.2006.0002

BASTOS, Maria Helena Camara. Da educação das meninas por Fénelon (1852). Revista História da Educação, Porto Alegre, v. 16, n. 36, p. 147-188, jan./ abr. 2012. https://doi.org/10.29388/978-85-53111-251-0-f. $97-108$

BENJAMIN, Walter. A tarefa do tradutor. Tradução de Fernando Camacho. In: BRANCO, Lúcia Castello (org.). A tarefa do tradutor, de Walter Benjamin: quatro traduções ao português. Belo Horizonte: FALE: UFMG, 2008. p. 25-49. https://doi.org/10.17851/23172096.25.2.209-224 
BERMAN, Antoine. A prova do estrangeiro: cultura e tradução na Alemanha romântica: Herder, Goethe, Schlegel, Novalis, Humboldt, Schleiermacher, Hölderlin. Tradução de Maria Emilia Pereira Chanut. Bauru: EDUSC, 2002. https://doi.org/10.11606/ issn.2317-9511.tradterm.2003.49099

BEZERRA, Mara Gonzalez. Tradução comentada da peça teatral Amor es más laberinto de Sor Juana Inés de La Cruz: o emaranhado jogo das antiteses. 2016. 281 f. Tese (doutorado) - Programa de Pós- Graduação em Estudos de Tradução, Universidade Federal de Santa Catarina, Florianópolis, 2016. Disponivel em: https://repositorio.ufsc.br/xmlui/ handle/123456789/172543. Acesso em: 30 jul. 2019. https://doi.org/10.5007/2177-5230.2010v26n50p215

BORBA, Cecilia de Souza. A luva negra de Juana Manuela Gorriti. Mafuá, Florianópolis, Santa Catarina, Brasil, n. 20, p. 1-24, 2013. Disponivel em: https:// mafua.ufsc.br/2013/a-luva-negra-de-juana-manuela-gorriti/. Acesso em: 29 jul. 2019. https://doi. org/10.11606/issn.2596-3147.v1i2p238-239

BOSI, Alfredo. História concisa da literatura brasileira 43 ed. São Paulo: Cultrix, 2006.

BOTTMANN, Denise. katherine mansfield no brasil. Postagem datada de 5 jun. 2016. Disponivel em: http:// naogostodeplagio.blogspot.com/2016/06/katherine-mansfield-no-brasil.html. Acesso em: 25 jul. 2019.

BRAVO, Victor. Libros clave de la narrativa venezolana (XI): Memorias de Mamá Blanca. Rinconete (Centro Virtual Cervantes), [S. l.], Jueves, 16 out. 2008 Disponivel em: https://cvc.cervantes.es/el_rinconete/anteriores/octubre_08/16102008_01.htm. Acesso em: 16 jul. 2019. https://doi.org/10.11606/d.8.2010. tde-26042010-164035

BURKE, Peter. Culturas da tradução nos primórdios da Europa Moderna. In: BURKE, Peter; R. PO-CHIA, Hisia (org.). A tradução cultural nos primórdios da Europa Moderna. Tradução de Roger Maioli dos Santos. São Paulo: Editora da Unesp, 2009. p. 13-46. https:// doi.org/10.5007/2175-7968.2009v2n24p258

CANDIDO, Antonio. A revolução de 1930 e a cultura. In: CANDIDO, Antonio. A educação pela noite e outros ensaios. São Paulo: Ática, 1989. p. 181-198.

CARVALHAL, Tania Franco. O próprio e o alheio: ensaios de literatura comparada. São Leopoldo: Editora da Universidade do Vale do Rio dos Sinos, 2003. 264p. https://doi.org/10.21041/conpat2019/v1cc306

CARVALHO, José Murilo de. Cidadania no Brasil: o longo caminho. 3. ed. Rio de Janeiro: Civilização Brasileira, 2002.

CARVALHO, José Murilo de. Fundamentos da politica e da sociedade brasileiras. In:

AVELAR, Lúcia; CINTRA, Antônio Octávio. Sistema politico brasileiro: uma introdução. 2. ed. rev. ampl. Rio de Janeiro: Konrad-Adenauer-Stifung; São Paulo: Editora Unesp, 2007. p. 19-34.
CUNHA, Roseli Barros. Aves sin nido, de Clorinda Matto de Turner - Tradução do IV capítulo do romance. Transversal - Revista em Tradução, Fortaleza, v. 3, n. 6, p. 27-29, 2017. Disponivel em: http://periodicos.ufc.br/transversal/article/ view/31632. Acesso em: 29 jul. 2019. https://doi. org/10.24824/978854443697.4

DALCASTAGNÉ, Regina. Um território contestado: literatura brasileira contemporânea e as novas vozes sociais., Iberic@l, Paris, n. 2, p. 13 - 18, 2012. Disponivel em: http://iberical.paris-sorbonne.fr/wp-content/uploads/2012/03/002-02.pdf. Acesso em: 26 jul. 2019. https://doi.org/10.18411/a-2017-023

DUARTE, Constância Lima. Feminismo e literatura no Brasil. São Paulo, Estudos Avançados, São Paulo, v. 17, n. 49, p. 151-172, 2003. Disponivel em: http:// www.revistas.usp.br/eav/article/view/9950. Acesso em: 15 out. 2019. https://doi.org/10.1590/s010340142003000300010

EVEN-ZOHAR, Itamar. A posição da literatura traduzida dentro do polissistema literário. Tradução de Leandro de Ávila Braga. Revista Translatio, Porto Alegre, n. 3, p. 3-10, 2012. Disponivel em: https://seer. ufrgs.br/translatio/article/view/34674/22321. Acesso em: 26 jul. 2019. https://doi.org/10.34019/19820836.2018.v22.25640

EVEN-ZOHAR, Itamar. Teoria dos polissistemas. Tradução de Luis Fernando Marozo, Carlos Rizzon e Yanna Karlla Cunha. Revista Translatio, Porto Alegre, n. 4, p. 0221, 2013. Disponivel em: https://seer.ufrgs.br/translatio/ article/view/42899/27134. Acesso em: 29 jul. 2019.

FERREIRA, Luzilá Gonçalves. Historia de las mujeres brasileñas en el siglo XIX: una lucha por visibilidad. In: GUARDIA, Sara Beatriz (ed.). Historia de las mujeres en América Latina. Lima: CEMHAL, 2003. p. 125-130. Disponivel em: https://www.um.es/estructura/unidades/u-igualdad/intranet/docs/historia-de-las-mujeres-en-america-latina.pdf. Acesso em: 15 out. 2019 https://doi.org/10.30827/arenal.vol25.num1.259-260

FERREIRA, Rocío. Clorinda Matto de Turner, novelista, y los aportes de Antonio Cornejo Polar al estudio de la novela peruana del siglo XIX. In: ENCUENTRO INTERNACIONAL MUJER E INDEPENDENCIAS, 2010., 1, [s/L]. Actas [...]. [S. l.]: CEMHAL, 2008. p. [1-13]. Disponivel em: https://cvc.cervantes.es/literatura/ mujer_independencias/ferreira01.htm. Acesso em: 25 jul. 2019. https://doi.org/10.2307/25070292

GOMES, Nathaly Silva Nalerio. Sonetos de Sor Juana Inés de la Cruz em português: dificuldades e soluções tradutórias. In: SANTOS, Amanda Basilio, MACHADO, Juliana Porto (org.) Fenômenos culturais no amálgama social: reunião de artigos do I CIPCS. Jaguarão: CLAEC, 2018. p. 1745-1759. Disponivel em: https://claec.org/editora/?page_id=292. Acesso em: 30 jul. 2019. https://doi.org/10.2307/j.ctvhno8rt.14

GUARDIA, Sara Beatriz. Literatura e escrita feminina na América Latina. Anuário de Literatura, Florianópolis, v. 18, n. esp. 1, p. 15-44, 2013. Disponivel em: https://periodicos.ufsc.br/index.php/literatura/article/view/28217. Acesso em: 28 jul. 2019. https://doi. org/10.5007/2175-7917.2013V18nesp1p15 
HALLEWELL, Laurence. O livro no Brasil: sua história. Tradução de Maria da Penha Villalobos, Lólio Lourenço de Oliveira e Geraldo Gerson de Souza. 3. ed. São Paulo: Editora da Universidade de São Paulo, 2012. https://doi.org/10.1590/1980436920170000000010

HOBSBAWM, Eric. Era dos extremos: o breve século XX (1914 - 1991). Tradução de Marcos Santarrita. São Paulo: Companhia das Letras, 1995.

HOUAISS, Antônio. Dicionário Eletrônico Houaiss da lingua portuguesa versão 3.0. rev., ampl. atual., São Paulo: Objetiva, 2009 [cd-rom]. https://doi. org/10.17979/rlex.2003.9.0.5582

IBGE. PNAD Contínua: $10 \%$ da população concentravam quase metade da massa de rendimentos do país em 2017. Agência de Notícias IBJE, Rio de Janeiro, 11 abr. 2018. Disponivel em https://agenciadenoticias.ibge.gov.br/agencia-sala-de-imprensa/2013-agencia-de-noticias/ releases/20843-pnad-continua-10-da-populacao-concentravam-quase-metade-da-massa-de-rendimentos-do-pais-em-2017. Acesso em: 26 jul. 2019. https://doi.org/10.21528/cbic2011-06.3

IBGE. Anuário Estatistico do Brasil. v. 78. Rio de Janeiro: IBGE, 2018. (Tabela 2.1.1.1 - População nos Censos Demográficos, segundo o sexo, os grupos de idade, o estado conjugal, a religião, a nacionalidade e a alfabetização - 1872/2010). Disponivel em: https:// biblioteca.ibge.gov.br/visualizacao/periodicos/20/ aeb_2018.pdf. Acesso em 27 jul. 2019. https://doi. org/10.5151/9cidi-congic-1.0393

JUANA INÉS. Criada por Patricia Arriaga-Jordán. Série original Netflix, 2016. 7 episódios. Disponivel em: https://www.netflix.com/br/title/80123792. Acesso em: 11 jul. 2019.

KAHMANN, Andrea Cristiane. O norte de Sur e as condicionantes para manter-se ao centro: o caso de María Luisa Bombal. Pelotas, Caderno de Letras, Pelotas, n. 30, p. 29 - 47, 2018. Disponivel em: https:// periodicos.ufpel.edu.br/ojs2/index.php/cadernodeletras/article/view/13757. Acesso em: 29 jul. 2019. https://doi.org/10.15210/cdl.voi30.13757

KARAM, Sergio Bandeira. A tradução de literatura hispano-americana no Brasil: um capitulo da história da literatura brasileira. 2016. 268 f. Dissertação (Mestrado em Letras) - Instituto de Letras, Universidade do Rio Grande do Sul, Porto Alegre, 2016. Disponivel em: https://lume.ufrgs.br/handle/10183/172902. Acesso em: 29 jul. 2019. https://doi.org/10.29381/01038559/2019290128-33

L\&PM. Coleção L\&PM Pocket [Catálogo]. Disponivel em: https://www.lpm.com.br/site/default.asp?TroncolD $=805134 \&$ Secao $\mid D=836333 \&$ Subsecao $I D=0$. Acesso em: 7 jan. 2014

LEFEVERE, André. Tradução, reescritura e manipulação da fama literária. Tradução de Claudia Matos Seligmann. Bauru: Edusc, 2007. https://doi.org/10.5007/2175-7968.2011v1n27p321
Lentz, Gleiton; Agustini, Delmira. Alguns cálices d'Os Cálices Vazios. Cadernos de Literatura em Tradução, São Paulo, n. 8, p. 179-201. 2007. Disponivel em: http://www.revistas.usp.br/clt/article/view/49436. Acesso em: 30 jul. 2019.

MERCOSUL. Comissão Permanente de Gênero e Direito das Mulheres da Reunião de Altas Autoridades em Direitos Humanos e Chancelaria do MERCOSUL (RAADH). Manual pedagógico sobre el uso del lenguaje inclusivo y no sexista. Buenos Aires, IPPDH, 2018. Disponivel em: http://www.ippdh.mercosur. int/pt-br/publicaciones/manual-pedagogico-sobre-o-uso-da-linguagem-inclusiva-nao-sexista. Acesso em: 15 out. 2019. https://doi.org/10.12818/p. 0.304-2340.2018v72p329

NAVARRO, Márcia Hoppe. O discurso crítico feminista na América Hispânica. In: SCHMIDT, Rita Terezinha (org.). Mulheres e literatura: (trans)formando identidades. Porto Alegre: Palloti, 1997. p. 39-49.

OLIVEIRA, Maria Clara Castellões de. Tradução \& gênero: tradutoras brasileiras nas décadas de 1930 e 1940. In: AMORIM, Lauro Maia; RODRIGUES, Cristina Carneiro; STUPIELLO, Érika Nogueira de Andrade. Tradução \& perspectivas teóricas e práticas. São Paulo: Editora Unesp Digital, 2015. (p. 123-153.). https:// doi.org/10.7476/9788568334614

ORTEGA Y GASSET, José. Miseria y esplendor de la traducción: traduções sinóticas. Scientia Traductionis, Florianópolis, n. 13, p. 5-50, 2013. Disponivel em: https://periodicos.ufsc.br/index.php/scientia/article/ view/30232/25187. Acesso em 26 jul. 2019. https:// doi.org/10.5007/1980-4237.2013n13p5

PAES, José Paulo. Tradução: a ponte necessária. São Paulo: Ática, 1990.

QUIJANO, Anibal. Colonialidad del poder, eurocentrismo y America Latina. In: QUIJANO, Anibal. Cuestiones y horizonte: de la dependencia histórico-estructural a la colonialidad/descolonialidad del poder. Buenos Aires: CLACSO, 2014. (Colección Antologias). Disponivel em: http://biblioteca.clacso. edu.ar/clacso/se/ 20140507042402/eje3-8.pdf. Acesso em: 25 jul. 2019. https://doi.org/10.22201/ cela.24484946e.2010.25.49411

REAL ACADEMIA ESPAÑOLA. Diccionario de la Real Academia Española. Disponivel em: https://dle.rae.e. Acesso em: 29 jul. 2019. https://doi.org/10.5944/ epos.17.2001.10203

RIO GRANDE DO SUL. Secretaria de Politicas para as mulheres. Grupo de Trabalho (Dec.Est. n ${ }^{\circ}$ 49.995/2012).

TOLEDO, Leslie Campaner de et al (org.). Manual para uso não sexista da linguagem. Porto Alegre: Secretaria de Comunicação e Inclusão Digital, 2014.

SANTOS, Boaventura de Sousa. Para além do pensamento abissal: das linhas globais a uma ecologia de saberes. In: SANTOS, B. S; MENESES, M. P. (org.). Epistemologias do sul. São Paulo: Cortez, 2010. p. 3183. https://doi.org/10.2307/j.ctvt6rkt3.18 
SARLO, Beatriz. Modernidade periférica: Buenos Aires 1920 e 1930. Tradução de Júlio Pimentel Pinto. São Paulo: Cosac Naify, 2010.

SILVA, Barbara Zocal da; BEZERRA, Wilson Alves. Aquém das fronteiras: a produção e a tradução literária de autoras latino-americanas. Cadernos de Literatura em Tradução, São Paulo, n. 21, p. 7-12, 2019. Disponivel em: http://www.revistas.usp.br/clt/article/ view/160383. Acesso em: 15 out. 2019. https:// doi.org/10.11606/issn.2359-5388

SPIVAK, Gayatri Chakravorty. Tradução como cultura. Tradução de Eliana Ávila e Liane Schneider. Ilha do Desterro, Florianópolis, n. 48, p. 41-64, jan./jun. 2005. Disponivel em: https://periodicos.ufsc.br/ index.php/desterro/article/download/9833/9064 Acesso em: 29 jul. 2019. https://doi.org/10.5007/ 2175-8026.2019v72n2pg

TORRES, Marie Helene Catherine. Best-sellers em tradução: o substrato cultural internacional. Alea, Rio de Janeiro, n. 2, v. 11, n. 2, p. 278-283, dez. 2009. Disponivel em: http://w/ww.scielo.br/scielo.php?script=sci_arttext\&pid=S1517-106X2009000200006. Acesso em: 27 jul. 2019. https://doi.org/10.1590/ \$1517-106×2009000200006

VALDERÓN, Roberto A. Translation and the Spanish Empire in the Americas. Amsterdam: Benjamins Translation Library, 2014.

VALLERIUS, Denise Mallmann. Borges em nova tradução: regionalismo para além das fronteiras. Porto Alegre: Editora da UFRGS, 2010.

VAZ, Artur Emilio Alarcon, PILETTI, Daniele Corbetta, NOAL, Joselma Noal (org.). Contos de Juana Manuela Gorriti. Tradução de Daniela Corbetta Piletti et. al. São Paulo: LiberArs, 2017. https://doi.org/10.5935/19806914/letras.v19n3p155-167

WYLER, Lia. Lingua, poetas e bacharéis: uma crônica da tradução no Brasil. Rio de Janeiro: Rocco, 2003. https://doi.org/10.7202/011616ar

\section{Endereço para correspondência}

Andrea Cristiane Kahmann

Universidade Federal de Pelotas - Colegiado de Letras - Tradução Espanhol/ Português

Rua Gomes Carneiro, 1, sala 107.

Centro, 96010-610

Pelotas, RS, Brasil

\section{Andrea Cristiane Kahmann}

Professora do Bacharelado em Letras - Tradução Espanhol / Português e do Programa de Pós-Graduação em Letras (Linha de Literatura, Cultura e Tradução) da Universidade Federal de Pelotas (https://wp.ufpel. edu.br/ppgl//). 